P

\section{Periodische Beinbewegungen}

Helga Peter

Marburg, Deutschland

\section{Synonyme}

Periodische Gliedmaßenbewegungen

\section{Englischer Begriff}

periodic leg movements

\section{Definition}

Älterer Begriff für periodische Extremitätenbewegungen. 